\title{
Recent Trends on the Dehydrogenation Catalysis of Liquid Organic Hydrogen Carrier (LOHC): A Review
}

\author{
Yasushi Sekine $^{1}$ (i) $\cdot$ Takuma Higo $^{1}$ \\ Accepted: 18 May 2021 / Published online: 27 May 2021 \\ (c) The Author(s) 2021
}

\begin{abstract}
Considering the expansion of the use of renewable energy in the future, the technology to store and transport hydrogen will be important. Hydrogen is gaseous at an ambient condition, diffuses easily, and its energy density is low. So liquid organic hydrogen carriers (LOHCs) have been proposed as a way to store hydrogen in high density. LOHC can store, transport, and use hydrogen at high density by hydrogenation and dehydrogenation cycles. In this review, we will focus on typical LOHCs, methylcyclohexane (MCH), 18H-dibenzyltoluene (DBT), and 12H-N-ethylcarbazole (NECZ), and summarize recent developments in dehydrogenation catalytic processes, which are key in this cycle.
\end{abstract}

Keywords Dehydrogenation $\cdot$ Reaction mechanism $\cdot$ Liquid organic hydrogen carrier $\cdot$ Methylcyclohexane $\cdot$ Stability

\section{Introduction}

In order to achieve carbon neutrality by 2050 , we need to flexibly change our social systems of energy and materials around the world. In the field of energy, solar cells are becoming more widespread and less costly, and electricity derived from a variety of renewable energy sources such as wind power is being expanded. These are great energy sources if they can be used immediately on the spot, but on the other hand, transporting the electricity over long distances via copper wires is highly impairing, and it is difficult to store the electricity on a large scale. Since the time and place of generation of renewable energy is in a different phase from that of the users, we need to think of ways to use renewable energy while shifting time and place. Figure 1 compares the energy densities of hydrogen gas, some liquid organic hydrogen carriers, batteries, synthetic fuels, etc., with respect to volume and weight $[1,2]$. As can be seen from this figure, batteries can store less energy per weight than synthetic fuels and hydrogen. The simplest option is to convert electricity to hydrogen. If conduits exist to transport hydrogen, it is desirable to transport it directly through pipelines. On the other hand, pipelines to transport hydrogen are

Yasushi Sekine

ysekine@waseda.jp

1 Applied Chemistry, Waseda University, 3-4-1, Okubo, Shinjuku, Tokyo 169-8555, Japan difficult to achieve in some cases due to the physical properties of hydrogen (i.e. it is easy to diffuse and leak, etc.). In such cases, one possible solution is to confine the hydrogen in the form of an energy carrier. So far, ammonia, hydrazine, FT (Fischer Tropsch) fuel, methanol, ethanol, formic acid, and organic hydrides have been proposed as energy carriers to store hydrogen. Among these, organic hydrides are expected to be used in a wide variety of applications because of their excellent long-term storage properties and stability at room temperature [1]. In this review, we will focus on dehydrogenation catalysts for these various organic hydrides and summarize their current status and issues.

\section{Catalysts for Dehydrogenation of Methylcyclohexane}

Among various organic hydrides, methylcyclohexane $(\mathrm{MCH})$ is said to be promising in terms of its high affinity with conventional petroleum refining and transport/storage/ distribution. Table 1 compares the physical and chemical properties of organic hydride with gaseous hydrogen and ammonia [1,2]. When MCH is used as a liquid organic hydrogen carrier (LOHC), the dehydrogenation reaction of $\mathrm{MCH}$ to toluene shown in the Eq. 1 must be carried out efficiently and selectively over a metal catalyst. 
Fig. 1 A comparison of the same amount of energy; all of these are equal to be 11.4 $\mathrm{MJ}=1 \mathrm{Nm}^{3}$ of hydrogen $[1,2]$
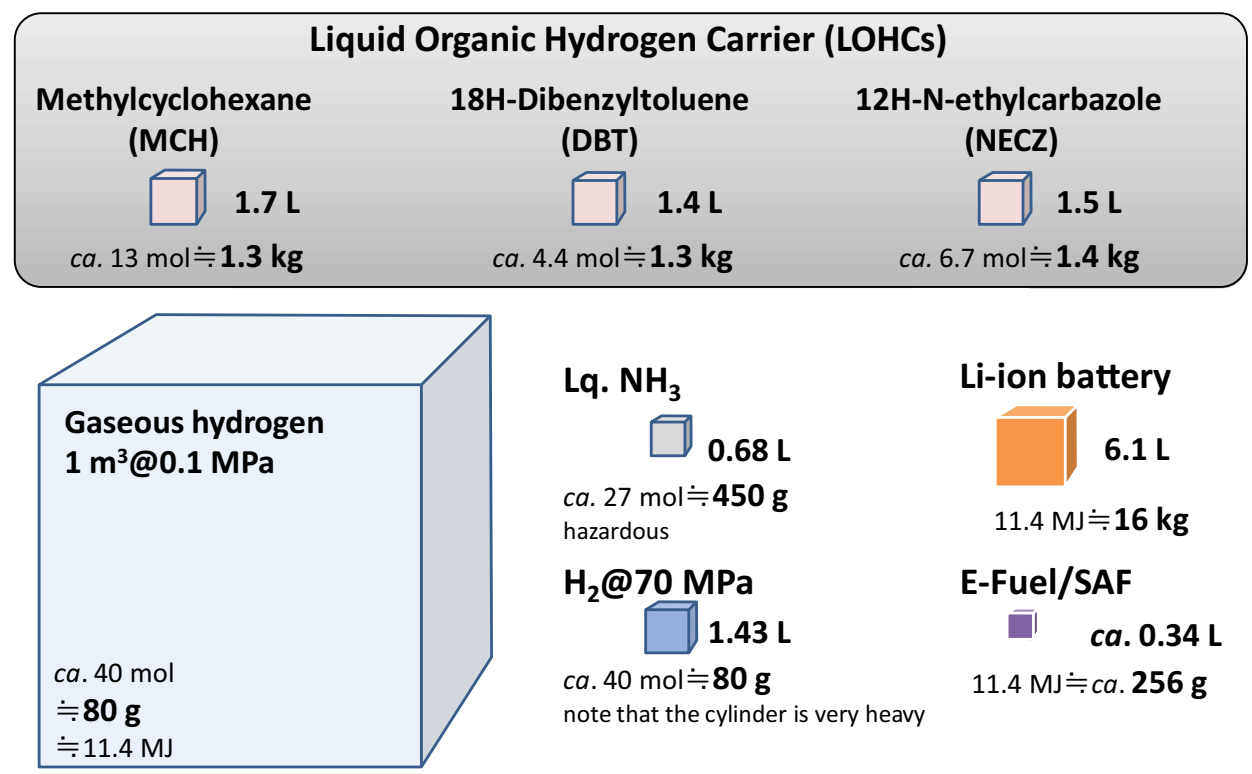

Lq. $\mathrm{NH}_{3}$

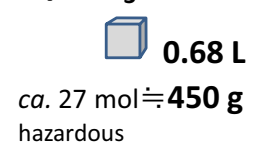

$\mathrm{H}_{2} @ 70 \mathrm{MPa}$

$1.43 \mathrm{~L}$

ca. $40 \mathrm{~mol} \fallingdotseq 80 \mathrm{~g}$

note that the cylinder is very heavy

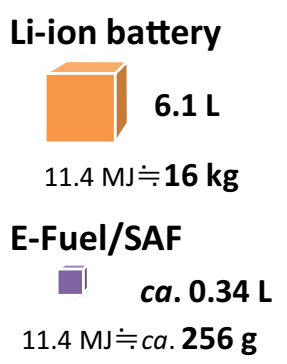

Table 1 Comparison of $\mathrm{MCH}$ and other hydrogen carrier including gaseous hydrogen $[1,2]$

\begin{tabular}{|c|c|c|c|c|c|c|}
\hline & $\begin{array}{l}\text { Hydrogen (gase- } \\
\text { ous) }\end{array}$ & $\mathrm{MCH}$ & $\begin{array}{l}\text { 18H-Dibenzyltol- } \\
\text { uene }\end{array}$ & $\begin{array}{l}12 \mathrm{H}-\mathrm{N} \text {-ethylcar- } \\
\text { bazole }\end{array}$ & Liquified hydrogen & Ammonia \\
\hline Composition & $\mathrm{H}_{2}$ & $\mathrm{C}_{7} \mathrm{H}_{14}$ & $\mathrm{C}_{21} \mathrm{H}_{38}$ & $\mathrm{C}_{14} \mathrm{H}_{25} \mathrm{~N}$ & $\mathrm{H}_{2}$ & $\mathrm{NH}_{3}$ \\
\hline Molecular weight & $2.0 \mathrm{~g} / \mathrm{mol}$ & $98.2 \mathrm{~g} / \mathrm{mol}$ & $290 \mathrm{~g} / \mathrm{mol}$ & $207 \mathrm{~g} / \mathrm{mol}$ & $2.0 \mathrm{~g} / \mathrm{mol}$ & $17.0 \mathrm{~g} / \mathrm{mol}$ \\
\hline Boiling point & $20 \mathrm{~K}$ & $374 \mathrm{~K}$ & $627 \mathrm{~K}$ & $553 \mathrm{~K}$ & $20 \mathrm{~K}$ & $240 \mathrm{~K}$ \\
\hline $\begin{array}{l}\text { Combustion } \\
\text { enthalpy }\end{array}$ & $\begin{array}{l}285 \mathrm{~kJ} / \mathrm{mol} \\
142 \mathrm{~kJ} / \mathrm{g}\end{array}$ & $\begin{array}{l}\text { (only for dehydro- } \\
\text { genation) }\end{array}$ & $\begin{array}{l}\text { (only for dehydro- } \\
\text { genation) }\end{array}$ & $\begin{array}{l}\text { (only for dehydro- } \\
\text { genation) }\end{array}$ & $\begin{array}{l}286 \mathrm{~kJ} / \mathrm{mol} \\
141.8 \mathrm{~kJ} / \mathrm{g}\end{array}$ & $\begin{array}{l}382.6 \mathrm{~kJ} / \mathrm{mol} \\
22.5 \mathrm{~kJ} / \mathrm{g}\end{array}$ \\
\hline $\begin{array}{l}\text { Enthalpy for } \\
\text { hydrogen evolu- } \\
\text { tion }\end{array}$ & - & $59.4 \mathrm{~kJ} / \mathrm{mol}-\mathrm{H}_{2}$ & $65 \mathrm{~kJ} / \mathrm{mol}-\mathrm{H}_{2}$ & $53 \mathrm{~kJ} / \mathrm{mol}^{-\mathrm{H}_{2}}$ & $0.899 \mathrm{~kJ} / \mathrm{mol}-\mathrm{H}_{2}$ & $30.8 \mathrm{~kJ} / \mathrm{mol}-\mathrm{H}_{2}$ \\
\hline $\begin{array}{l}\text { Hydrogen density } \\
\text { by volume }\end{array}$ & $\begin{array}{l}55 \mathrm{~kg} / 1 \mathrm{~m}^{3} \\
(70 \mathrm{MPa})\end{array}$ & $47.3 \mathrm{~kg} / 1 \mathrm{~m}^{3}$ & $56.4 \mathrm{~kg} / 1 \mathrm{~m}^{3}$ & $54.5 \mathrm{~kg} / 1 \mathrm{~m}^{3}$ & $70.6 \mathrm{~kg} / 1 \mathrm{~m}^{3}$ & $121 \mathrm{~kg} / 1 \mathrm{~m}^{3}$ (Liq.) \\
\hline $\begin{array}{l}\text { Hydrogen density } \\
\text { by weight }\end{array}$ & $100 \mathrm{wt} \%$ & $6.16 \mathrm{wt} \%$ & $6.21 \mathrm{wt} \%$ & $5.8 \mathrm{wt} \%$ & $100 \mathrm{wt} \%$ & $17.8 \mathrm{wt} \%$ \\
\hline Density & & $0.769 \mathrm{~g} / \mathrm{cm}^{3}$ & $0.91 \mathrm{~g} / \mathrm{cm}^{3}$ & $0.94 \mathrm{~g} / \mathrm{cm}^{3}$ & $0.0706 \mathrm{~g} / \mathrm{cm}^{3}$ & $0.682 \mathrm{~g} / \mathrm{cm}^{3} \mathrm{Liq}$ \\
\hline Explosion limit & $4.1-74.2$ vol $\%$ & $\begin{array}{l}1.4-6.7 \text { vol\% } \\
\text { (toluene) }\end{array}$ & No data & No data & $4.1-74.2 \mathrm{vol} \%$ & $15-28$ vol\% \\
\hline Toxicity & No & Low & Low & Low & No & Very high \\
\hline
\end{tabular}

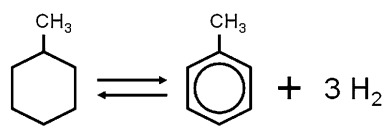

Many studies have been published on catalytic $\mathrm{MCH}$ dehydrogenation [2]. Dehydrogenation catalysts basically consist of fine particles of the active metal dispersed on a catalyst support like alumina. In such supported metal catalysts, the morphology of the active metal particles, the metal-support interaction, and the acidity of the support material are important factors. These determine the dehydrogenation activity, selectivities to products, and the catalyst stability. Since the dehydrogenation to toluene and the demethylation of toluene (i.e. a side reaction) proceed simultaneously on the metal surface, the morphology and electronic state control of the supported metal are important factors.

Wolf and Petersen conducted a study of dehydrogenation of $\mathrm{MCH}$ using a $0.6 \%$ platinum catalyst on $\gamma$-alumina in 1977 [3]. The reaction temperature was $623 \mathrm{~K}$, and the effect of partial pressure of hydrogen on the hydrogen poisoning was discussed. Furthermore, Corma et al. compared three different samples of platinum-loaded $\mathrm{NaY}$ zeolite catalysts with different degrees of metal dispersion to study the correlation between the catalyst structure and catalytic activity 
[4]. Coughlin et al. studied the effect of sulfur coexistence and showed that a little pre-sulfurization of the catalyst increased the yield of toluene on the Pt catalyst [5]. Furthermore, they studied the effect of small amounts of sulfur in detail, and showed that carbon deposition was greatly suppressed by the presence of small amounts of hydrogen sulfide [6]. In the same year, Touzani et al. investigated the kinetics and showed that the dehydrogenation rate of $\mathrm{MCH}$ depends only on the partial pressure of $\mathrm{MCH}$ [7]. Thus, by the early 1980s, the basic knowledge about dehydrogenation catalysis of MCH had been established. Subsequently, there were a series of reports on the process and demonstrations. Yolcular et al. found that even nickel catalysts can also show stable activity for the dehydrogenation of MCH [8]. Shukla et al. reported the performance of lanthanum oxide and perovskite as supports of Pt clusters [9]. The kinetic model is discussed in detail in literature [10], and it is shown that the reaction is well explained when non-Langmuir adsorption isotherms are used. Furthermore, Ali et al. showed that dehydrogenation beyond equilibrium was possible using a catalytic reactor with a palladium-silver tubular membrane to separate the produced hydrogen in-situ. Using a pre-sulfurized catalyst, conversions of four times the equilibrium value were obtained over a period of $300 \mathrm{~h}$ at temperatures as low as $573 \mathrm{~K}$ [11]. Okada et al. introduces a pre-sulfurized catalyst that can show high activity and stability over a long period, taking advantage of the $\mathrm{MCH}$ dehydrogenation technology for hydrogen stations [12].

Based on this knowledge in the past masterpieces, we will discuss the recent research trends for these 5 years in Pt-based catalysts and other metal catalysts, and catalytic processes for dehydrogenation of $\mathrm{MCH}$ in this section.

\subsection{Recent Reports on Pt-based Catalysts for MCH Dehydrogenation}

Pt-based catalysts are the most widely studied catalysts because of their ability to activate $\mathrm{C}-\mathrm{H}$ bonds and their high dehydrogenation activity compared to other metal catalysts. The basic policy to enhance the performance of Pt-based catalysts is to increase the number of active sites by increasing the dispersion of supported Pt and to control the electronic state of Pt. The specific methods include the design of the support material and bimetallization by adding different metals. The addition of different metals can change the structure (geometrical factor) and electronic state (electronic factor) of Pt sites and improve the catalytic performance compared to monometallic Pt catalysts. A variety of second metal-Pt bimetallic catalysts have been studied as dehydrogenation catalysts for various hydrocarbons $[2,13,14]$ (see Table 2). Recently, Yan et al. [15] reported that the addition of $\mathrm{Sn}$ to $\mathrm{Pt} / \mathrm{Mg}-\mathrm{Al}-\mathrm{O}$ catalyst significantly enhanced
Table 2 Comparative table of recently reported catalysts for $\mathrm{MCH}$ dehydrogenation; note that the conversion strongly depends on the catalyst amount and space velocity

\begin{tabular}{|c|c|c|c|c|}
\hline Catalyst & $\begin{array}{l}\text { Reaction } \\
\text { temperature/K }\end{array}$ & $\begin{array}{l}\text { MCH conversion/ } \\
\text { toluene selectivity } \\
(\%)\end{array}$ & $\mathrm{H}_{2}$ formation rate & References \\
\hline $2 \mathrm{wt} \% \mathrm{Pt}-1 \mathrm{wt} \% \mathrm{Sn} / \mathrm{Mg}-\mathrm{Al}$ oxide & 573 & $71 /-$ & $205.6 \mathrm{mmol} \mathrm{g} / \mathrm{Pt} / \mathrm{min}$ & [15] \\
\hline $2 \mathrm{wt} \% \mathrm{Pt}-3 \mathrm{wt} \% \mathrm{Sn} / \mathrm{Mg}-\mathrm{Al}$ oxide & 573 & 81.1/- & $234.9 \mathrm{mmol} \mathrm{g} / \mathrm{Pt} / \mathrm{min}$ & [15] \\
\hline $2 \mathrm{wt} \% \mathrm{Pt}-5 \mathrm{wt} \% \mathrm{Sn} / \mathrm{Mg}-\mathrm{Al}$ oxide & 573 & $90.5 /-$ & $262.1 \mathrm{mmol} \mathrm{g} / \mathrm{Pt} / \mathrm{min}$ & {$[15]$} \\
\hline \multirow[t]{2}{*}{$0.4 \mathrm{wt} \% \mathrm{Pt} / \mathrm{Ce}-\mathrm{Mg}-\mathrm{Al}$ oxide } & 573 & $-1-$ & $686.9 \mathrm{mmol} \mathrm{g} / \mathrm{Pt} / \mathrm{min}$ & {$[15]$} \\
\hline & 623 & $-1-$ & $1358.6 \mathrm{mmol} \mathrm{g} / \mathrm{Pt} / \mathrm{min}$ & [15] \\
\hline $0.5 \mathrm{wt} \% \mathrm{Pt} / \mathrm{Al}_{2} \mathrm{O}_{3}$ & 673 & $75.2 / 99.1$ & $1380 \mathrm{~mol} \mathrm{~mol} / \mathrm{Pt} / \mathrm{h}$ & [17] \\
\hline $0.5 \mathrm{wt} \% \mathrm{Pt} / \mathrm{TiO}_{2}-\mathrm{Al}_{2} \mathrm{O}_{3}$ & 673 & $93.2 / 99.1$ & $1711 \mathrm{~mol} \mathrm{~mol} / \mathrm{Pt} / \mathrm{h}$ & {$[17]$} \\
\hline $0.5 \mathrm{wt} \% \mathrm{Pt} / \mathrm{TiO}_{2}$ & 673 & $67.4 / 99.9$ & $1237 \mathrm{~mol} \mathrm{~mol} / \mathrm{Pt}_{\mathrm{t}} / \mathrm{h}$ & [17] \\
\hline Pt/Silicalite-1 & 623 & $17.7 /-$ & $82.43 \mathrm{mmol} \mathrm{g} / \mathrm{Pt} / \mathrm{min}$ & [16] \\
\hline $\mathrm{Cu}-\mathrm{Pt} /$ Silicalite-1 & 623 & $59.4 /-$ & $288.9 \mathrm{mmol} \mathrm{g} / \mathrm{Pt} / \mathrm{min}$ & {$[16]$} \\
\hline $1 \mathrm{wt} \% \mathrm{Pt} / \gamma-\mathrm{Al}_{2} \mathrm{O}_{3}$ & 623 & $85.9 / 99.9$ & - & {$[24]$} \\
\hline $1 \mathrm{wt} \% \mathrm{Pt}-1.4 \mathrm{wt} \% \mathrm{Mn} / \gamma-\mathrm{Al}_{2} \mathrm{O}_{3}$ & 623 & $85-90 />99.9$ & & [13] \\
\hline $\mathrm{Pt} / \mathrm{USY}$ & 523 & $3.9 / 20$ & - & [22] \\
\hline $\mathrm{Pd} / \mathrm{USY}$ & 523 & $2.9 / 1$ & - & [22] \\
\hline $\mathrm{Ir} / \mathrm{USY}$ & 523 & $9.7 / 89$ & - & [22] \\
\hline $\mathrm{Ni} / \mathrm{USY}$ & 523 & $5.5 / 10$ & - & [22] \\
\hline $10 \mathrm{wt} \% \mathrm{Ni} / \gamma-\mathrm{Al}_{2} \mathrm{O}_{3}$ & 623 & $36.2 / 66.9$ & - & {$[24]$} \\
\hline $8 \mathrm{wt} \% \mathrm{Ni}-2 \mathrm{wt} \% \mathrm{Ag} / \gamma-\mathrm{Al}_{2} \mathrm{O}_{3}$ & 623 & $14.7 / 71.7$ & - & [24] \\
\hline $8 \mathrm{wt} \% \mathrm{Ni}-2 \mathrm{wt} \% \mathrm{Sn} / \gamma-\mathrm{Al}_{2} \mathrm{O}_{3}$ & 623 & $16.0 / 93.2$ & - & [24] \\
\hline $8 \mathrm{wt} \% \mathrm{Ni}-2 \mathrm{wt} \% \mathrm{Zn} / \gamma-\mathrm{Al}_{2} \mathrm{O}_{3}$ & 623 & $32.2 / 96.6$ & - & [24] \\
\hline $8 \mathrm{wt} \% \mathrm{Ni}-2 \mathrm{wt} \% \mathrm{In} / \gamma-\mathrm{Al}_{2} \mathrm{O}_{3}$ & 623 & $9.8 / 99.5$ & - & [24] \\
\hline
\end{tabular}


the $\mathrm{MCH}$ dehydrogenation activity, which was attributed to the electron donation from $\mathrm{Sn}$ to $\mathrm{Pt}$ and the adjustment of the interaction of $\mathrm{MCH}$ and the resulting toluene with the Pt surface. On the other hand, when excess Sn is added, the surface Pt sites are diluted by the formation of Pt-Sn alloy, and the activity decreases. Such a decrease in the conversion rate due to the dilution of $\mathrm{Pt}$ sites by the excess of the second metal was also observed in $\mathrm{Pt} / \mathrm{Mo}-\mathrm{SiO}_{2}$ catalysts. Nakano et al. found that adding a small amount of Mn to $\mathrm{Pt} / \mathrm{Al}_{2} \mathrm{O}_{3}$ suppressed the demethylation reaction of toluene without reducing the $\mathrm{MCH}$ conversion [13]. Manabe et al. [14] attributed this suppression of the side reaction to the selective coating of $\mathrm{MnO}_{x}$ on the coordination unsaturated sites of Pt, which was revealed by a combination of XAFS measurements and DFT calculations. Also, the MCH dehydrogenation performance of $\mathrm{Cu}-\mathrm{Pt}$ bimetallic catalysts has been investigated in detail; Zhang et al. [16] found that the $\mathrm{Cu}$ addition improved the MCH conversion of Pt/Silicalite-1 (S-1) from 17.7 to $59.4 \%$ under the same conditions, and the toluene selectivity was $99.6 \%$. The high conversion rate was attributed to the improvement of $\mathrm{Pt}$ dispersion and sintering resistance by alloying with $\mathrm{Cu}$. It was also experimentally shown that the electron density of Pt may be relatively reduced by intermetallic electron transfer. It is believed that excessive hydrogenation and hydrogenolysis are suppressed on the Pt with low electron density, resulting in high selectivity.

As for the catalyst support, the most basic support is $\mathrm{Al}_{2} \mathrm{O}_{3}[13,14,17-20]$, and as other options, $\mathrm{Mg}-\mathrm{Al}-\mathrm{O}$ [15, 21], USY zeolite [22], $\mathrm{TiO}_{2}[17,23], \mathrm{TiO}_{2}-\mathrm{Al}_{2} \mathrm{O}_{3}$ [17, 20], and Silicalite-1 [16] are reported. In addition to the role of high dispersion of Pt particles, the support material is also expected to suppress the aggregation of Pt particles by strong metal-support interaction (SMSI) (anchoring effect) and electron transfer between Pt and support. Wang et al. reported that $\mathrm{Pt} / \mathrm{Ce}-\mathrm{Mg}-\mathrm{Al}-\mathrm{O}$, which is $\mathrm{Mg}-\mathrm{Al}-\mathrm{O}$ combined with a small amount of $\mathrm{Ce}$, shows high $\mathrm{MCH}$ dehydrogenation activity with a conversion rate of $98.5 \%$ [21]. The addition of $\mathrm{CeO}_{2}$ to the support has been found to improve the dispersion of Pt particles. Although the surface area of $\mathrm{TiO}_{2}$ is lower than that of $\mathrm{Al}_{2} \mathrm{O}_{3}$ and zeolite, it has been reported that $\mathrm{TiO}_{2}$ has a strong interaction with $\mathrm{Pt}$ and has several interesting support effects. Nagatake et al. found that $\mathrm{Pt} /$ $\mathrm{TiO}_{2}$ is a more stable dehydrogenation catalyst than $\mathrm{Pt} / \mathrm{Al}_{2} \mathrm{O}_{3}$ because it is less susceptible to the reaction inhibition effect of adsorption of product toluene [23]. The effect of electron donation from $\mathrm{TiO}_{2}$ to $\mathrm{Pt}$ has been reported by Sugiura et al. [20] and Yang [17]. Sugiura et al. focused on the relationship between methane by-products and Pt electronic state on Pt/ $\mathrm{TiO}_{2}-\mathrm{Al}_{2} \mathrm{O}_{3}$, and found that the greater the electron donation from $\mathrm{TiO}_{2}$ to $\mathrm{Pt}$, the more the demethylation of toluene is suppressed.
As for the precious metal catalyst other than Pt, Cromwell et al. [22] reported that monometallic Ir catalyst showed better dehydrogenation performance than Pt catalyst. Under the reaction conditions of $523 \mathrm{~K}, 3 \mathrm{MPa}$ total hydrogen pressure, and $\mathrm{WHSV}=92.4 / \mathrm{h}, \mathrm{Ir} / \mathrm{USY}$ was about 11 times higher in toluene yield than Pt/USY. However, the Ir/USY catalyst showed 0\% toluene selectivity ( $89 \%$ cyclohexane selectivity) when the reaction temperature was raised to $573 \mathrm{~K}$. This was attributed to the preferential dealkylation of $\mathrm{MCH}$ molecules due to the acidic nature of the USY support. Although the Ir catalyst was shown to be superior to the Pt catalyst in this reaction condition, Ir is a noble metal like Pt, so the cost advantage is low. If the amount of Ir used can be reduced while maintaining catalytic performance exceeding that of Pt by appropriate selection of support materials and catalyst design such as bimetallicization by adding a second metal, Ir may become a superior alternative to Pt.

\subsection{Recent Reports on Non-platinum Based Catalysts for MCH Dehydrogenation}

Although Pt catalysts exhibit high dehydrogenation activity, the high cost and the amount of Pt present have led to the development of alternative catalysts. Ali et al. reported the mono-metallic ( $\mathrm{Ni}, \mathrm{Ag}, \mathrm{Zn}, \mathrm{Sn}$, and $\mathrm{In}$ ) and bimetallic Ni catalysts (Ni-Ag, Ni-Zn, Ni-Sn, and Ni-In) supported on $\mathrm{Al}_{2} \mathrm{O}_{3}$ showed a conversion of $36.2 \%$ and a toluene selectivity of $66.9 \%$ at $623 \mathrm{~K}$, indicating that $\mathrm{Ni} / \mathrm{Al}_{2} \mathrm{O}_{3}$ has the potential to replace $\mathrm{Pt}$ among mono-metallic catalysts [24]. The conversion on other monometallic catalysts was less than $1 \%$. For improving the activity of Ni-catalyst, a second metal was added as the bimetallic $\mathrm{Ni}(\mathrm{Ni}-\mathrm{Ag}, \mathrm{Ni}-\mathrm{Zn}, \mathrm{Ni}-\mathrm{Sn}$. and $\mathrm{Ni}-\mathrm{In}$ ) catalyst, The performance of bimetallic $\mathrm{Ni}(\mathrm{Ni}-\mathrm{Ag}, \mathrm{Ni}-\mathrm{Zn}, \mathrm{Ni}-\mathrm{Sn}$, and $\mathrm{Ni}-\mathrm{In})$ catalysts was improved by adding secondary metals. From the DFT calculations [18], it is concluded that the $\mathrm{Zn}$ coating of the low coordination sites, where $\mathrm{C}-\mathrm{C}$ cleavage occurs preferentially, suppresses the demethylation reaction, and achieves high selectivity.

\subsection{Recent Reports on the Kinetics and Reaction Mechanism on the MCH Dehydrogenation}

In the use of precious metals such as Pt and Ir, and base metals such as $\mathrm{Ni}$, kinetics and reaction mechanisms are important in considering activity and selectivity as a catalyst. Akram et al. [19] used a number of kinetic equations derived from power-law kinetics and Langmuir-Hinshelwood-HougenWatson (LHHW) kinetics to determine the kinetic models for $\mathrm{MCH}$ dehydrogenation over monometallic and bimetallic Pt-supported- $\mathrm{Al}_{2} \mathrm{O}_{3}$ catalysts. They show that the kinetic model based on the single-site surface reaction mechanism [Eqns. (2-6)] best reproduces the experimental data and that 
the "the loss of first molecular hydrogen" step in Eq. 3 is the rate-limiting step.

$\mathrm{C}_{7} \mathrm{H}_{14}+\sigma \rightleftharpoons \mathrm{C}_{7} \mathrm{H}_{14} \cdot \sigma$

$\mathrm{C}_{7} \mathrm{H}_{14} \cdot \sigma \rightleftharpoons \mathrm{C}_{7} \mathrm{H}_{12} \cdot \sigma+\mathrm{H}_{2}$

$\mathrm{C}_{7} \mathrm{H}_{12} \cdot \sigma \rightleftharpoons \mathrm{C}_{7} \mathrm{H}_{10} \cdot \sigma+\mathrm{H}_{2}$

$\mathrm{C}_{7} \mathrm{H}_{10} \cdot \sigma \rightleftharpoons \mathrm{C}_{7} \mathrm{H}_{8} \cdot \sigma+\mathrm{H}_{2}$

$\mathrm{C}_{7} \mathrm{H}_{8} \cdot \sigma \rightleftharpoons \mathrm{C}_{7} \mathrm{H}_{8}+\sigma$

Here, $\sigma$ denotes the active site of the catalyst. It is also mentioned that the final product, toluene, inhibits the reaction due to its strong adsorption on the catalyst surface. Similar observations on the rate-limiting step of the reaction have been made by several groups in experimental kinetic investigations combined with kinetics modeling [25-28]. In addition, density functional theory (DFT) studies of the dehydrogenation of MCH to toluene on a Pt (111) surface have shown that the first dehydrogenation step, which has the highest energy barrier, may determine the overall rate of the reaction $[29,30]$.

Thus, several studies support the view that the first dehydrogenation step from $\mathrm{MCH}\left(\mathrm{C}_{7} \mathrm{H}_{14}\right)$ to methylcyclohexene $\left(\mathrm{C}_{7} \mathrm{H}_{12}\right)$ is the rate-limiting step in the $\mathrm{MCH}$ dehydrogenation reaction on $\mathrm{Pt}$ surfaces, while other views have been proposed. Zhao et al. [31] investigated the dehydrogenation reactivity of $\mathrm{Pt}_{13}$ clusters supported on alumina (100) surface using density functional theory (DFT) and $a b$-initio molecular dynamics. The optimal reaction pathway was found to be a combination of six $\mathrm{C}-\mathrm{H}$ bond cleavage and $\mathrm{H}$ diffusion and cluster reconstruction steps. As a result, the $\mathrm{C}-\mathrm{H}$ bond dissociation (the third $\mathrm{C}-\mathrm{H}$ dissociation) step of $\mathrm{C}_{7} \mathrm{H}_{12}$ was the most energetic one at the reaction temperature of $625 \mathrm{~K}$. This finding suggests that the active site reconstruction itself should be considered as an elementary reaction and that the conventional Langmuir-Hinshelwood type theory may not be directly applicable. In the catalytic MCH dehydrogenation process, a number of side reactions can also proceed. Since the presence of by-products other than hydrogen and toluene has a significant impact on the stability and economics of the process operation, it is desirable to minimize the byproducts as much as possible and proceed with the dehydrogenation to toluene in a highly selective manner. In particular, methane by-products reduce the purity of the exit gas hydrogen, and coke formation causes irreversible degradation of the dehydrogenation catalyst activity. Alhumaidan et al. have studied the $\mathrm{MCH}$ dehydrogenation over $\mathrm{Pt} / \mathrm{Al}_{2} \mathrm{O}_{3}$ catalysts and the associated side reactions
(Fig. 2), and revealed the effect of side reactions on the long-term deactivation of the catalyst [32]. They evaluated the operating parameters (the reactor space-time (W/F), pressure, temperature, and $\mathrm{H}_{2} / \mathrm{MCH}$ ratio) that affect the by-product yields. Among the many side reactions, benzene formation was reported to be the most productive and sensitive to operating parameters. The rate of demethylation of toluene to form benzene increased significantly with increasing the reaction temperature and pressure. In a practical LOHC system based on the MCH-toluene- $\mathrm{H}_{2}$ cycle, the demethylation of toluene is considered to be the most critical side reaction because the system needs to be operated at relatively high temperature and pressure. It was also shown that the demethylation reaction and the formation of coke precursor (cyclopentadiene, etc.) can be reduced by coexisting $\mathrm{H}_{2}$ in the feed at a moderate ratio. In order to increase the feasibility of the process, it is important to develop a highly engineered catalytic process that can suppress side reactions and selectively promote the dehydrogenation of $\mathrm{MCH}$ to toluene.

\subsection{Recent Trend on Catalytic Processes on the Dehydrogenation of MCH}

\subsubsection{Application of a Membrane Reactor}

Since MCH dehydrogenation is a highly endothermic reaction, a high operating temperature is required due to the limitation of thermodynamic equilibrium in the case of a typical fixed bed reactor. In addition, a separation system is required to increase the purity of the outlet gas, which increases the cost of the process. Membrane reactor (MR) technology has received much attention as an approach to solve these drawbacks. Membrane reactors can shift the equilibrium of dehydrogenation to the product side by selectively separating $\mathrm{H}_{2}$ from the reaction zone in-situ. As a result, higher $\mathrm{MCH}$ conversions can be achieved at lower temperatures than in conventional fixed bed reactors, and the separation process in the subsequent stages can be simplified. In fact, Kreuder et al. [33] have successfully tested $\mathrm{MCH}$ dehydrogenation in a planar fixed-bed microreactor (Fig. 3) with microstructured channels combining a catalystfilled bed and a Pd membrane. Simulation studies have also been conducted to predict the reaction behavior and optimize the reactor for various forms of MR [34, 35]. Byun et al. [36] compared the technical and economic aspects of the $\mathrm{MCH}$ dehydrogenation reaction using MR and a conventional packed-bed reactor (PBR). The cost estimation based on the process simulation shows that the unit $\mathrm{H}_{2}$ production cost of PBR is 11.76, 9.50, 8.50, and 8.08 dollars and that of MR is 9.37, 7.43, 6.58, and 6.23 dollars for $\mathrm{H}_{2}$ production capacities of $30,100,300$, and $700 \mathrm{~m}^{3} / \mathrm{h}$, respectively. 


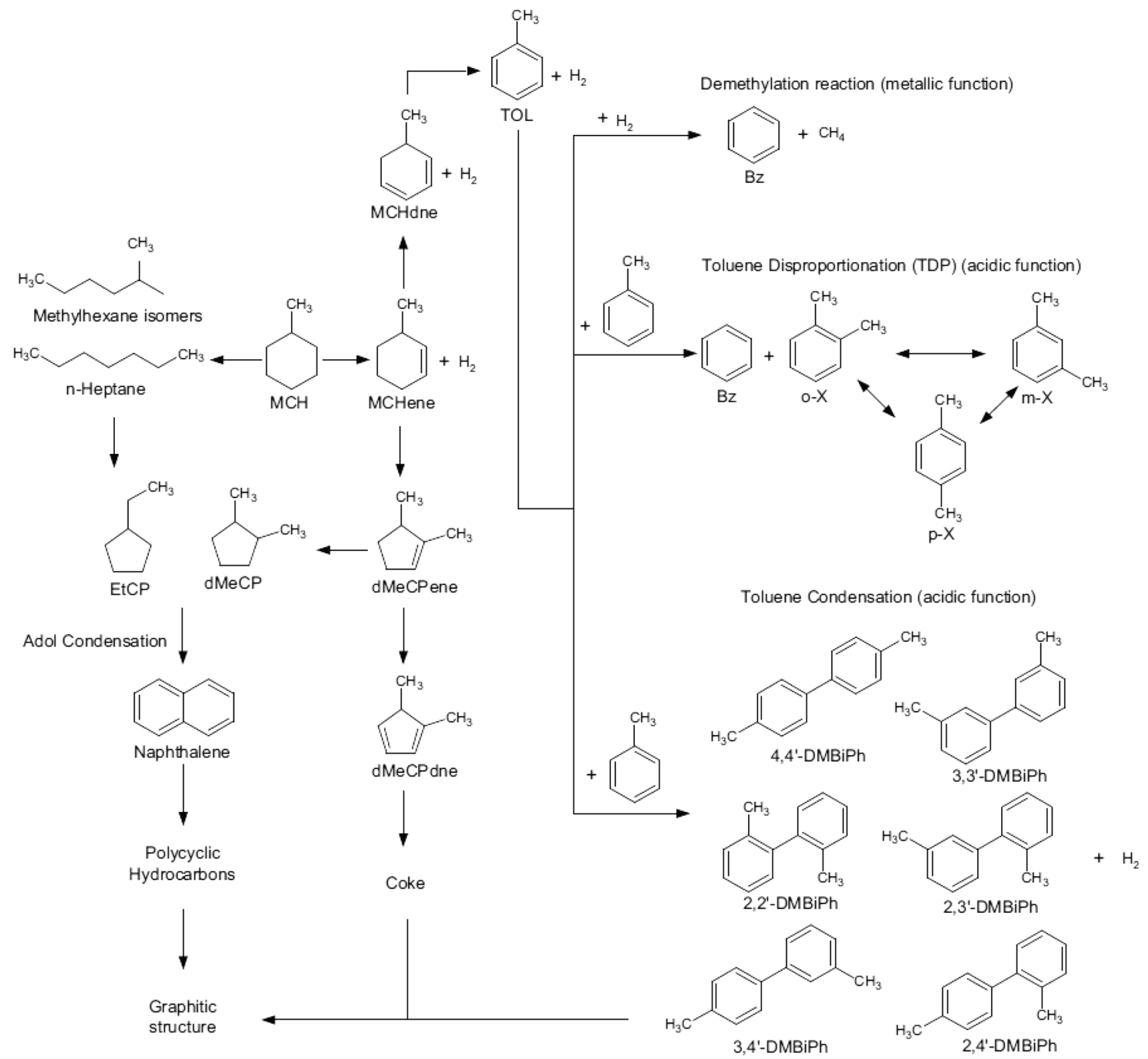

Fig. 2 Reaction pathways for $\mathrm{MCH}$ dehydrogenation and associated side reactions. $\mathrm{MCH}$ methylcyclohexane, MCHene methylcyclohexene, MCHdne methylcyclohexadiene, TOL toluene, BZ benzene,

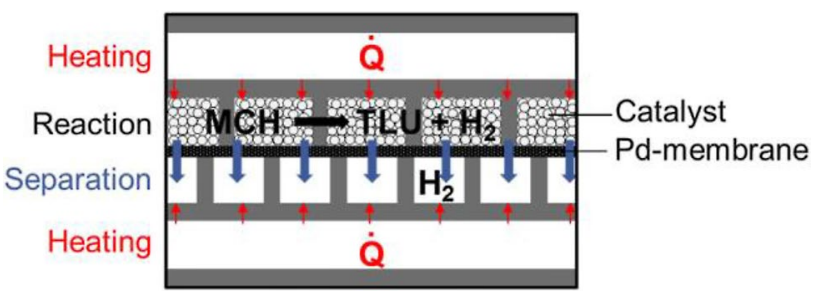

Fig. 3 Schematic image of the microstructured reactor with an integrated Pd-membrane reprinted from Ref. 21 $o, m, p-X$ ortho, meta, para-xylene, $E t C P$ ethylcyclopentane, $d M e C P$ dimethylcyclopentane, $D M B i P h$ dimethylbiphenyl reprinted from Ref. 32

\subsubsection{Application of an Electric Field for Catalytic MCH Dehydrogenation}

Since MCH dehydrogenation is an endothermic reaction, it is necessary to provide heat for the reaction. If the reaction can be driven by low-temperature waste heat $(<473 \mathrm{~K})$ that exists in the $\mathrm{H}_{2}$ utilization area, it will be possible to construct a hydrogen supply chain with less energy loss as a whole. However, conventional catalytic processes cannot achieve sufficient hydrogen yield at low temperatures due to both of the kinetic limitation and the thermodynamic 
equilibrium constraint. To solve this problem, unconventional $\mathrm{MCH}$ dehydrogenation processes have been proposed in which a weak electric field is applied to the catalyst bed [37-39]. It has been reported that the application of a weak electric field to a catalyst such as $\mathrm{Pt} / \mathrm{CeO}_{2}$ or $\mathrm{Pt} / \mathrm{TiO}_{2}$ greatly enhances the dehydrogenation activity and results in $\mathrm{MCH}$ conversions that exceed thermodynamic equilibrium. The selectivity of toluene in this reaction is more than $99 \%$, and the $\mathrm{MCH}$ dehydrogenation reaction is stable and highly selective with no or less deactivation over time. Takise et al. [37, 38] have conducted various kinetic analyses to elucidate the detailed mechanism of the electric field MCH dehydrogenation reaction. The dependence of the reaction rate on the partial pressures of the reactants $(\mathrm{MCH})$ and products (toluene and $\mathrm{H}_{2}$ ) was evaluated, and it was found that the dehydrogenation rate in the conventional thermally catalyzed reaction is negatively dependent on the $\mathrm{H}_{2}$ partial pressure, while it is positively dependent in the catalytic reaction under an electric field. In addition, kinetic analysis using isotopic substrates $\left(D_{2}\right.$ and $\left.C_{7} D_{14}\right)$ shows that the rate constant increases with the use of isotopic substrates $\left(k_{\mathrm{D}} / k_{\mathrm{H}}>1\right)$, indicating a reverse isotope effect in the catalytic reaction under the electric field. This suggests that the dehydrogenation reaction is promoted by $\mathrm{H}_{2}$ or its derived species present in the system. Based on a series of kinetic analyses, we speculate that the activation of the $\mathrm{MCH}$ molecule occurs thanks to collisions with $\mathrm{H}^{+}$conducting across the catalyst surface. It is concluded that the dehydrogenation proceeds via the intermediate $\left[\mathrm{C}_{7} \mathrm{H}_{13}-\mathrm{H}-\mathrm{H}\right]^{+}$due to the collision of conduction $\mathrm{H}^{+}$and $\mathrm{MCH}$ on the catalyst with the applied electric field. Since the $\mathrm{C}-\mathrm{H}$ bond dissociation via a triatomic intermediate such as $\mathrm{C}-\mathrm{H}-\mathrm{H}^{+}$is irreversible, we consider that the $\mathrm{MCH}$ dehydrogenation reaction, which does not follow the conventional thermodynamic equilibrium theory, is driven by the electric field applied catalytic reaction. The application of the catalytic reaction under the electric field has demonstrated that it drives the irreversible $\mathrm{MCH}$ dehydrogenation reaction in the low-temperature range. In addition to the design of optimal catalyst materials, further research on the design of electric-field catalytic reactors for the scale-up of the process is expected in the future.

\section{Catalytic Dehydrogenation of Other LOHCs}

There is a wide range of LOHC candidates other than the methylcyclohexane being considered to date, and it is necessary to carefully determine which LOHC systems are most promising for later social implementation. Niermann et al. [40] presented a LOHC system employing seven different LOHCs (12H-N-ethylcarbazole, 18H-dibenzyltoluene, 1,2-dihydro-1,2-azaborine, formic acid, methanol, naphthalene, toluene). The suitability of the LOHC system for transportation and storage applications was evaluated from both technical and economic points of view. As a result, $18 \mathrm{H}$-dibenzyltoluene (18H-DBT) was shown to be an inexpensive LOHC option for storage and transportation along with methanol and toluene. In addition, $12 \mathrm{H}-\mathrm{N}$-ethylcarbazole (12H-NECZ) has been evaluated as a promising material for mobility applications [1]. Therefore, in this section, we will focus on DBT and NECZ, and the catalytic dehydrogenation studies of their hydrogenated products, $18 \mathrm{H}-$ DBT and 12H-NECZ, will be described in detail below (see Tables 3 and 4).
Table 3 Comparative table of recently reported catalysts for $18 \mathrm{H}$-dibenzyltoluene dehydrogenation

\begin{tabular}{lllll}
\hline Catalyst & $\begin{array}{l}\text { Reaction } \\
\text { temperature/K }\end{array}$ & $\begin{array}{l}\text { Reaction } \\
\text { time/min }\end{array}$ & $\begin{array}{l}\text { Dehydrogena- } \\
\text { tion rate } \%\end{array}$ & References \\
\hline $1 \mathrm{wt} \% \mathrm{Pt} / \mathrm{Al}_{2} \mathrm{O}_{3}$ & 593 & 80 & 80 & {$[42]$} \\
$1 \mathrm{wt} \% \mathrm{Pd} / \mathrm{Al}_{2} \mathrm{O}_{3}$ & 593 & 80 & 11 & {$[42]$} \\
$0.25 \mathrm{wt} \% \mathrm{~S}-0.3 \mathrm{wt} \% \mathrm{Pt} / \mathrm{Al}_{2} \mathrm{O}_{3}$ & 583 & 120 & $>90$ & {$[44]$} \\
$0.3 \mathrm{wt} \% \mathrm{Pd} / \mathrm{Al}_{2} \mathrm{O}_{3}$ & 583 & 120 & approx.80 & {$[44]$} \\
$5 \mathrm{wt} \% \mathrm{Pt} / \mathrm{CeO}_{2}$ prepared by GNP method & 573 & 150 & 80.5 & {$[45]$} \\
$5 \mathrm{wt} \% \mathrm{Pd} / \mathrm{Al}_{2} \mathrm{O}_{3}$ prepared by GNP method & 573 & 150 & 3.5 & {$[45]$} \\
$1 \mathrm{wt} \% \mathrm{Pd} / \mathrm{TiO}_{2}$ (anatase + rutile) & 563 & 45 & Approx. 65 & {$[47]$} \\
$1 \mathrm{wt} \% \mathrm{Pt} / \gamma-\mathrm{Al}_{2} \mathrm{O}_{3}$ & 563 & 45 & 55 & {$[47]$} \\
$1 \mathrm{wt} \% \mathrm{Pt} / \mathrm{C}$ & 563 & 45 & 68 & {$[47]$} \\
$5 \mathrm{wt} \% \mathrm{Pt} / \mathrm{Al}{ }_{2} \mathrm{O}_{3}$ & 543 & 300 & 56.3 & {$[48]$} \\
$5 \mathrm{wt} \% \mathrm{Pd} / \mathrm{HAP} \mathrm{PAP}$ & 300 & 27.7 & {$[48]$} \\
$5 \mathrm{wt} \% \mathrm{Pt} / \mathrm{SBA}-15$ & 543 & 300 & 34.2 & {$[48]$} \\
$5 \mathrm{wt} \% \mathrm{Pd} / \mathrm{C}$ & 543 & 300 & 58.2 & {$[48]$} \\
\hline
\end{tabular}


Table 4 Comparative table of recently reported catalysts for $12 \mathrm{H}-\mathrm{N}$-alkylcarbazole dehydrogenation

\begin{tabular}{|c|c|c|c|c|c|}
\hline Catalyst & Reactant & $\begin{array}{l}\text { Reaction } \\
\text { temperature/K }\end{array}$ & $\begin{array}{l}\text { Reaction } \\
\text { time/h }\end{array}$ & $\mathrm{H}_{2}$ release/wt $\%$ & References \\
\hline $\mathrm{Pd} / \mathrm{Al}_{2} \mathrm{O}_{3}$ & 12H-NPCZ & 453 & 4 & 4.59 & {$[53]$} \\
\hline $2.5 \mathrm{wt} \% \mathrm{Ru}-2.5 \mathrm{wt} \% \mathrm{Pd} / \mathrm{Al}_{2} \mathrm{O}_{3}$ & 12H-NPCZ & 453 & 4 & 5.38 & {$[53]$} \\
\hline $2.5 \mathrm{wt} \% \mathrm{Pd}-2.5 \mathrm{wt} \% \mathrm{Ru} / \mathrm{Al}_{2} \mathrm{O}_{3}$ & 12H-NPCZ & 453 & 4 & 4.72 & {$[53]$} \\
\hline 3wt\%Pd@MIL-101 & 12H-NPCZ & 463 & 4 & Above 4.81 & {$[57]$} \\
\hline $5 \mathrm{wt} \% \mathrm{Pt} / \mathrm{TiO}_{2}$ & 12H-NECZ & 453 & 7 & 5.38 & [49] \\
\hline $5 \mathrm{wt} \% \mathrm{Pd} / \mathrm{TiO}_{2}$ & 12H-NECZ & 453 & 7 & 5.25 & [49] \\
\hline $5 \mathrm{wt} \% \mathrm{Rh} / \mathrm{TiO}_{2}$ & 12H-NECZ & 453 & 7 & 3.72 & [49] \\
\hline $5 \mathrm{wt} \% \mathrm{Au} / \mathrm{TiO}_{2}$ & 12H-NECZ & 453 & 7 & 1.59 & [49] \\
\hline $0.6 \mathrm{wt} \% \mathrm{Rh}-1 \mathrm{wt} \% \mathrm{Pd} / \mathrm{Al}_{2} \mathrm{O}_{3}$ & 12H-NPCZ & 453 & 4 & 5.48 & {$[54]$} \\
\hline $5 \mathrm{wt} \% \mathrm{Pd} / \mathrm{C}$ & 12H-NECZ & 453 & 6 & 5.54 & {$[56]$} \\
\hline $5 \mathrm{wt} \% \mathrm{Pd} / \mathrm{Al}_{2} \mathrm{O}_{2}$ & 12H-NECZ & 453 & 8 & 5.56 & {$[56]$} \\
\hline $5 \mathrm{wt} \% \mathrm{Pd} / \mathrm{TiO}_{2}$ & 12H-NECZ & 453 & 10 & 5.56 & {$[56]$} \\
\hline Pd/reduced-Graphene oxide & 12H-NECZ & 453 & 7 & 5.74 & {$[51]$} \\
\hline $\mathrm{Pd}_{1.2} \mathrm{Cu} /$ reduced-Graphene oxide & 12H-NECZ & 453 & 7 & 5.79 & {$[55]$} \\
\hline
\end{tabular}

\subsection{Recent Reports on the Catalytic Dehydrogenation of $18 \mathrm{H}$-dibenzyltoluene}

Pt-based catalysts have been the most studied catalysts for the dehydrogenation of 18H-DBT. In fact, the most active catalysts reported in recent years are Pt-based catalysts (Table 3). The theoretical investigation using DFT calculations by Ouma et al. [41] shows that the activation energy for $18 \mathrm{H}$-DBT dehydrogenation is lower on the Pt surface than on the Pd surface. Modisha et al. [42] investigated the $18 \mathrm{H}-\mathrm{DBT}$ dehydrogenation performance of $\mathrm{Pt} / \mathrm{Al}_{2} \mathrm{O}_{3}, \mathrm{Pd} /$ $\mathrm{Al}_{2} \mathrm{O}_{3}$ and $\mathrm{Pt}-\mathrm{Pd} / \mathrm{Al}_{2} \mathrm{O}_{3}$ catalysts. The dehydrogenation rates obtained for Pt, Pd, and Pt-Pd catalysts were 82, 11, and $6 \%$, respectively, at $593 \mathrm{~K}$, and the monometallic Pt catalyst was reported to be significantly superior. However, $\mathrm{Pt} /$ $\mathrm{Al}_{2} \mathrm{O}_{3}$ has a relatively high concentration of methane as a by-product during the reaction. It is known that methane mixed in hydrogen fuel gas is difficult to remove and causes a decrease in the power output when fed to the fuel cell [43]. Therefore, it is desirable to develop more selective catalysts that can suppress side reactions. Auer et al. [44] found that sulfur coating of the low-coordination sites of Pt particles on $\mathrm{Pt} / \mathrm{Al}_{2} \mathrm{O}_{3}$ can suppress the side reactions. They also believe that the turnover rate of the reaction is improved as a result of the enhanced desorption of the dehydrogenation product, DBT, due to the change in the electronic state of $\mathrm{Pt}$ caused by the sulfur modification. In recent years, several studies on monometallic Pt catalysts supported on various support materials have been reported [45-48]. Lee et al. [45] synthesized $\mathrm{Pt} / \mathrm{Al}_{2} \mathrm{O}_{3}$ and $\mathrm{Pt} / \mathrm{CeO}_{2}$ using the glycine nitrate process (GNP) and investigated the dehydrogenation activity of $18 \mathrm{H}-\mathrm{DBT}$. The conversions of $\mathrm{Pt} / \mathrm{CeO}_{2}$ and $\mathrm{Pt} /$ $\mathrm{Al}_{2} \mathrm{O}_{3}$ were $80.5 \% / 2.5 \mathrm{~h}$ and $3.5 \% / 2.5 \mathrm{~h}$, respectively, and $\mathrm{Pt} / \mathrm{CeO}_{2}$ showed very high activity. The $\mathrm{Pt} / \mathrm{CeO}_{2}$ synthesized by the GNP method has a relatively large support surface area and pore size. It is considered that these features of catalyst resulted in the improved Pt dispersion and better diffusion of 18H-DBT molecules in the catalyst particles. They mention the need for more detailed studies on the diffusion of $18 \mathrm{H}-\mathrm{DBT}$ into the catalyst particle pores due to the larger molecular size of $18 \mathrm{H}-\mathrm{DBT}$ than $\mathrm{MCH}$. Shi et al. [46] have also studied the effect of surface hydroxyl groups and the surface oxygen vacancies (SOV) on the reversible hydrogenation and dehydrogenation reactivity of $18 \mathrm{H}-\mathrm{DBT}$ using $\mathrm{Pt} / \mathrm{Al}_{2} \mathrm{O}_{3}$ with controlled surface hydroxyl groups and SOV by a plasma treatment method. It was found that the surface hydroxyl groups increase the degree of reduction of the supported Pt by promoting hydrogen spillover, thereby improving the hydrogenation and dehydrogenation activities. It was also shown that increasing SOV increased the percentage of low-coordinated $\mathrm{Pt}$, which promoted side reactions. These findings indicate that controlling the surface properties of the support is an effective approach for designing high-performance $18 \mathrm{H}$-DBT dehydrogenation catalysts.

\subsection{Recent Reports on the Catalytic Dehydrogenation of $12 \mathrm{H}-\mathrm{N}$-ethylcarbazole (12H-NECZ)}

Although $12 \mathrm{H}-\mathrm{NECZ}$ is inferior to cycloalkanes in terms of $\mathrm{H}_{2}$ weight density, it can be a promising candidate for $\mathrm{LOHC}$ from the viewpoint of energy efficiency because of its ability to perform hydrogenation/dehydrogenation cycles at low temperatures below $473 \mathrm{~K}$. The bottleneck in the LOHC cycle using NECZ is the dehydrogenation of the hydride 12H-NECZ [49]. Therefore, the development of dehydrogenation catalysts with high activity and selectivity has become an important research topic. Yang et al. [50] studied the 
dehydrogenation of $12 \mathrm{H}-\mathrm{NECZ}$ using noble metal catalysts supported on $\mathrm{Al}_{2} \mathrm{O}_{3}$ and reported that the catalytic activity follows the order of $\mathrm{Pd}>\mathrm{Pt}>\mathrm{Ru}>\mathrm{Rh}>\mathrm{Au}$. In the study of graphene-supported noble metal catalysts by Wang et al. [51] reported in 2018, the dehydrogenation activity was also found to be $\mathrm{Pd}>\mathrm{Pt}>\mathrm{Rh}>\mathrm{Ru}>\mathrm{Au}$. Pd is expected to be a promising catalyst for the dehydrogenation of $12 \mathrm{H}-\mathrm{NECZ}$, and in fact, recent reports on the dehydrogenation of $12 \mathrm{H}-\mathrm{NECZ}$ (including some 12H-N-propylcarbazole (12H-NPCZ)) have focused on Pd base catalysts (Table 4). Dong et al. [52] conducted a kinetic study of the 12H-NPCZ dehydrogenation over $\mathrm{Pd} / \mathrm{Al}_{2} \mathrm{O}_{3}$. They reported that the dehydrogenation pathway involves three successive steps: $12 \mathrm{H}-\mathrm{NPCZ} \rightarrow 8 \mathrm{H}-\mathrm{NPCZ} \rightarrow 4$ $\mathrm{H}-\mathrm{NPCZ} \rightarrow \mathrm{NPCZ}$, with the $4 \mathrm{H}-\mathrm{NPCZ} \rightarrow \mathrm{NPCZ}$ step, which has the highest activation energy, being the rate-limiting step. In order to improve the performance of Pd catalysts and reduce the amount of Pd used, there are several reports on bimetallic Pd catalysts with the addition of a second metal [53-55]. Wang et al. [55] developed a bimetallic Pd-Cu/graphene catalyst with $12 \mathrm{H}-\mathrm{NECZ}$ dehydrogenation activity comparable to that of Pd/graphene while reducing the amount of Pd used. The high activity was attributed to the reduction of Pd particle size by $\mathrm{Cu}$ addition (geometric effect). In addition, when the replacement ratio of $\mathrm{Pd}$ with $\mathrm{Cu}$ is more than $50 \%$, electron transfer from $\mathrm{Pd}$ to $\mathrm{Cu}$ starts to occur and the dehydrogenation activity decreases (electronic effect). In addition to the active metal, the support material is also considered to be a factor that affects the catalytic activity. Feng et al. [56] investigated the 12H-NECZ dehydrogenation activity of Pd nanoparticle catalysts supported on four different supports (activated carbon, $\mathrm{Al}_{2} \mathrm{O}_{3}, \mathrm{TiO}_{2}$, and $\mathrm{SiO}_{2}$ ) and reported that the order of dehydrogenation activity was $\mathrm{Pd} / \mathrm{C}>\mathrm{Pd} / \mathrm{Al}_{2} \mathrm{O}_{3}>\mathrm{Pd} / \mathrm{TiO}_{2}>\mathrm{Pd} /$ $\mathrm{SiO}_{2}$. The kinetic analysis indicates that the rate-limiting step of the dehydrogenation reaction may be different for each carrier. It was confirmed that the state of supported Pd, such as particle size and degree of reduction, varies greatly depending on the support. Jiang et al. [49] compared the dehydrogenation performance of precious metal catalysts supported on $\mathrm{TiO}_{2}$ and found that $\mathrm{Pt} / \mathrm{TiO}_{2}$ showed higher activity and selectivity than $\mathrm{Pd} / \mathrm{TiO}_{2}$ and $\mathrm{Pd} / \mathrm{Al}_{2} \mathrm{O}_{3}$. We believe that the electron transfer from $\mathrm{TiO}_{2}$ to $\mathrm{Pd}$ is the reason for the higher performance of the Pd catalyst, but further studies are needed to clarify the effect in more detail.

\section{Conclusion}

In this review, recent trends on the catalytic dehydrogenation of $\mathrm{MCH}$ and other LOHCs are summarized. LOHCs are very good candidates for storing hydrogen stably even at an ambient condition. In the hydrogenation-dehydrogenation cycle of LOHC, the hydrogenation step is exothermic and rather easy, so the dehydrogenation of LOHC (endothermic) is important. It requires external heat, so high energy efficiency is anticipated. Also, a selective and stable reaction process is desired. For these purposes, designing a metal catalyst with analytical feedback and a computational prediction is very important. Further investigation for enhancing the dehydrogenation at low temperature is also required, including the utilization of membrane and/or electric field.

\section{Declarations}

Conflict of interest The authors have no conflicts of interest to declare that are relevant to the content of this article.

Open Access This article is licensed under a Creative Commons Attribution 4.0 International License, which permits use, sharing, adaptation, distribution and reproduction in any medium or format, as long as you give appropriate credit to the original author(s) and the source, provide a link to the Creative Commons licence, and indicate if changes were made. The images or other third party material in this article are included in the article's Creative Commons licence, unless indicated otherwise in a credit line to the material. If material is not included in the article's Creative Commons licence and your intended use is not permitted by statutory regulation or exceeds the permitted use, you will need to obtain permission directly from the copyright holder. To view a copy of this licence, visit http://creativecommons.org/licenses/by/4.0/.

\section{References}

1. Niermann M, Beckendorff A, Kaltschmitt M, Bonhoff K (2019) Liquid organic hydrogen carrier (LOHC) — assessment based on chemical and economic properties. Int J Hydrogen Energy 44:6631-6654

2. Gianotti E, Taillades-Jacquin M, Rozière J, Jones DJ (2018) Highpurity hydrogen generation via dehydrogenation of organic carriers: a review on the catalytic process. ACS Catal 8:4660-4680

3. Wolf EE, Petersen EE (1977) Kinetics of deactivation of a reforming catalyst during methylcyclohexane dehydrogenation in a diffusion reactor. J Catal 46:190-203

4. Corma A, Reyes P, Pajares JA (1982) Metal dispersity and activity for methylcyclohexane dehydrogenation on $\mathrm{Pt} / \mathrm{NaY}$ zeolite. React Kinet Catal Lett 18:79-84

5. Coughlin RW, Kawakami K, Hasan A, Buu P (1982) Dynamic activation, deactivation, and coking on PT and PTRE catalysts for dehydrogenation of methylcyclohexane (MCH). Stud Surf Sci Catal 11:307-314

6. Coughlin RW, Hasan A, Kawakami K (1984) Activity, yield patterns, and coking behavior of Pt and PtRe catalysts during dehydrogenation of methylcyclohexane: II Influence of sulfur. J Catal 88:163-176

7. Touzani A, Klvana D, Belanger G (1984) Dehydrogenation of methylcyclohexane on the industrial catalyst: kinet study. Stud Surf Sci Catal 19:357-364

8. Yolcular $\mathrm{S}$, Olgun $\mathrm{O}(2008) \mathrm{Ni} / \mathrm{Al}_{2} \mathrm{O}_{3}$ catalysts and their activity in dehydrogenation of methylcyclohexane for hydrogen production. Catal Today 138:198-202

9. Shukla AA, Gosavi PV, Pande JV, Kumar VP, Chary KVR, Biniwale RB (2010) Efficient hydrogen supply through catalytic 
dehydrogenation of methylcyclohexane over Pt/metal oxide catalysts. Int J Hydrogen Energy 35:4020-4026

10. Alhumaidan F, Cresswell D, Garforth A (2011) Kinetic model of the dehydrogenation of methylcyclohexane over monometallic and bimetallic Pt catalysts. Ind Eng Chem Res 50:2509-2522

11. Ali JK, Newson EJ, Rippin DWT (1994) Exceeding equilibrium conversion with a catalytic membrane reactor for the dehydrogenation of methylcyclohexane. Chem Eng Sci 49:2129-2134

12. Okada Y, Sasaki E, Watanabe E, Hyodo S, Nishijima H (2006) Development of dehydrogenation catalyst for hydrogen generation in organic chemical hydride method. Int J Hydrogen Energy 31:1348-1356

13. Nakano A, Manabe S, Higo T, Seki H, Nagatake S, Yabe T, Ogo S, Nagatsuka T, Sugiura Y, Iki H, Sekine Y (2017) Effects of Mn addition on dehydrogenation of methylcyclohexane over $\mathrm{Pt} / \mathrm{Al}_{2} \mathrm{O}_{3}$ catalyst. Appl Catal A 543:75-81

14. Manabe S, Yabe T, Nakano A, Nagatake S, Higo T, Ogo S, Nakai $\mathrm{H}$, Sekine Y (2018) Theoretical investigation on structural effects of Pt-Mn catalyst on activity and selectivity for methylcyclohexane dehydrogenation. Chem Phys Lett 711:73-76

15. Yan J, Wang W, Miao L, Wu K, Chen G, Huang Y, Yang Y (2018) Dehydrogenation of methylcyclohexane over Pt-Sn supported on $\mathrm{Mg}-\mathrm{Al}$ mixed metal oxides derived from layered double hydroxides. Int J Hydrogen Energy 43:9343-9352

16. Zhang X, He N, Lin L, Zhu Q, Wang G, Guo H (2020) Study of the carbon cycle of a hydrogen supply system over a supported $\mathrm{Pt}$ catalyst: methylcyclohexane-toluene-hydrogen cycle. Catal Sci Technol 10(4):1171-1181

17. Yang X, Song Y, Cao T, Wang L, Song H, Lin W (2020) The double tuning effect of $\mathrm{TiO}_{2}$ on Pt catalyzed dehydrogenation of methylcyclohexane. Mol Catal 492:110971

18. Al-ShaikhAli AH, Jedidi A, Anjum DH, Cavallo L, Takanabe K (2017) Kinetics on NiZn bimetallic catalysts for hydrogen evolution via selective dehydrogenation of methylcyclohexane to toluene. ACS Catal 7:1592-1600

19. Akram MS, Aslam R, Alhumaidan FS, Usman MR (2020) An exclusive kinetic model for the methylcyclohexane dehydrogenation over alumina-supported Pt catalysts. Int J Chem Kinet 52(7):415-449

20. Sugiura Y, Nagatsuka T, Kubo K, Hirano Y, Nakamura A, Miyazawa K, lizuka Y, Furuta S, Iki H, Higo T, Sekine Y (2017) Dehydrogenation of methylcyclohexane over $\mathrm{Pt} / \mathrm{TiO}_{2}-\mathrm{Al}_{2} \mathrm{O}_{3}$ catalysts. Chem Lett 46(11):1601-1604

21. Wang W, Miao L, Wu K, Chen G, Huang Y, Yang Y (2019) Hydrogen evolution in the dehydrogenation of methylcyclohexane over $\mathrm{Pt} / \mathrm{Ce}-\mathrm{Mg}-\mathrm{Al}-\mathrm{O}$ catalysts derived from their layered double hydroxides. Int J Hydrogen Energy 44:2918-2925

22. Cromwell DK, Vasudevan PT, Pawelec B, Fierro JLG (2016) Enhanced methylcyclohexane dehydrogenation to toluene over Ir/USY catalyst. Catal Today 259:119-129

23. Nagatake S, Higo T, Ogo S, Sugiura Y, Watanabe R, Fukuhara C, Sekine Y (2016) Dehydrogenation of methylcyclohexane over Pt/ $\mathrm{TiO}_{2}$ catalyst. Catal Lett 146(1):54-60

24. Al-ShaikhAli AH, Jedidi A, Cavallo L, Takanabe K (2015) Non-precious bimetallic catalysts for selective dehydrogenation of an organic chemical hydride system. Chem Commun 51:12931-12934

25. Usman M, Cresswell D, Garforth A (2012) Detailed reaction kinetics for the dehydrogenation of methylcyclohexane over $\mathrm{Pt}$ catalyst. Ind Eng Chem Res 51:158-170

26. Van Trimpont PA, Marin G, Froment G (1986) Kinetics of methylcyclohexane dehydrogenation on sulfided commercial platinum/ alumina and platinum-rhenium/alumina catalysts. Ind Eng Chem Fundam 25:544-553
27. Corma A, Cid R, Agudo AL (1979) Catalyst decay in the kinetics of methylcyclohexane dehydrogenation over Pt-NaY zeolite. Can J Chem Eng 57:638-642

28. García de la Banda JF, Corma A, Melo FV (1986) Dehydrogenation of methylcyclohexane on a PtNaY catalyst. Study of kinetics and deactivation. Appl Catal 26:103-121

29. Mi C, Huang Y, Chen F, Wu K, Wang W, Yang Y (2021) Density functional theory study on dehydrogenation of methylcyclohexane on Ni-Pt(111). Int J Hydrogen Energy 46(1):875-885

30. Chen F, Huang Y, Mi C, Wu K, Wang W, Li W, Yang Y (2020) Density functional theory study on catalytic dehydrogenation of methylcyclohexane on $\operatorname{Pt}(111)$. Int J Hydrogen Energy 45(11):6727-6737

31. Zhao W, Chizallet C, Sautet P, Raybaud P (2019) Dehydrogenation mechanisms of methyl-cyclohexane on $\gamma-\mathrm{Al}_{2} \mathrm{O}_{3}$ supported $\mathrm{Pt}_{13}$ : impact of cluster ductility. J Catal 370:118-129

32. Alhumaidan F, Tsakiris D, Cresswell D, Garforth A (2013) Hydrogen storage in liquid organic hydride: selectivity of $\mathrm{MCH}$ dehydrogenation over monometallic and bimetallic Pt catalysts. Int $\mathbf{J}$ Hydrogen Energy 38:14010-14026

33. Kreuder H, Boeltken T, Cholewa M, Meier J, Pfeifer P, Dittmeyer $\mathrm{R}$ (2016) Heat storage by the dehydrogenation of methylcyclohexane-experimental studies for the design of a microstructured membrane reactor. Int J Hydrogen Energy 41:12082-12092

34. Chen YR, Tsuru T, Kang DY (2017) Simulation and design of catalytic membrane reactor for hydrogen production via methylcyclohexane dehydrogenation. Int J Hydrogen Energy 42:26296-26307

35. Ghasemzadeh K, Ghahremani M, Amiri TY, Basile A, Iulianelli A (2021) Hydrogen production by silica membrane reactor during dehydrogenation of methylcyclohexane: CFD analysis. Int J Hydrogen Energy. https://doi.org/10.1016/j.ijhydene.2020.05. 046 (in press)

36. Byun M, Kim H, Choe C, Lim H (2021) Conceptual feasibility studies for cost-efficient and bi-functional methylcyclohexane dehydrogenation in a membrane reactor for $\mathrm{H}_{2}$ storage and production. Energy Convers Manage 227:113576

37. Takise K, Sato A, Murakami K, Ogo S, Seo JG, Imagawa K, Kado S, Sekine Y (2019) Irreversible catalytic methylcyclohexane dehydrogenation by surface protonics at low temperature. RSC Adv 9:5918-5924

38. Takise K, Sato A, Ogo S, Seo JG, Imagawa K, Kado S, Sekine Y (2019) Low-temperature selective catalytic dehydrogenation of methylcyclohexane by surface protonics. RSC Adv 9:27743-27748

39. Kosaka M, Higo T, Ogo S, Seo JG, Imagawa K, Kado S, Sekine Y (2020) Low-temperature selective dehydrogenation of methylcyclohexane by surface protonics over Pt/anatase- $\mathrm{TiO}_{2}$ catalyst. Int J Hydrogen Energy 45(1):738-743

40. Niermann M, Drunert S, Kaltschmitt M, Bonhoff K (2019) Liquid organic hydrogen carriers (LOHCs) — techno-economic analysis of LOHCs in a defined process chain. Energy Environ Sci 12:290-307

41. Ouma CNM, Modisha PM, Bessarabov D (2020) Catalytic dehydrogenation onset of liquid organic hydrogen carrier, perhydrodibenzyltoluene: the effect of Pd and Pt subsurface configurations. Comput Mater Sci 172:109332

42. Modisha P, Gqogqa P, Garidzirai R, Ouma CNM, Bessarabov D (2019) Evaluation of catalyst activity for release of hydrogen from liquid organic hydrogen carriers. Int J Hydrogen Energy 44:21926-21935

43. Lee S, Han G, Kim T, Yoo YS, Jeon SY, Bae J (2020) Connected evaluation of polymer electrolyte membrane fuel cell with dehydrogenation reactor of liquid organic hydrogen carrier. Int J Hydrogen Energy 45(24):13398-13405 
44. Auer F, Blaumeiser D, Bauer T, Bösmann A, Szesni N, Libuda J, Wasserscheid P (2019) Boosting the activity of hydrogen release from liquid organic hydrogen carrier systems by sulfur-additives to Pt on alumina catalysts. Catal Sci Technol 9(13):3537-3547

45. Lee S, Lee J, Kim T, Han G, Lee J, Lee K, Bae J (2021) Pt/CeO catalyst synthesized by combustion method for dehydrogenation of perhydrodibenzyltoluene as liquid organic hydrogen carrier: effect of pore size and metal dispersion. Int J Hydrogen Energy 46:5520-5529

46. Shi L, Zhou Y, Qi S, Smith KJ, Tan X, Yan J, Yi C (2020) Pt catalysts supported on $\mathrm{H}_{2}$ and $\mathrm{O}_{2}$ plasma-treated $\mathrm{Al}_{2} \mathrm{O}_{3}$ for hydrogenation and dehydrogenation of the liquid organic hydrogen carrier pair dibenzyltoluene and perhydrodibenzyltoluene. ACS Catal 10(18):10661-10671

47. Aakko-Saksa PT, Vehkamäki M, Kemell M, Keskiväli L, Simell P, Reinikainen M, Tapper U, Repo T (2020) Hydrogen release from liquid organic hydrogen carriers catalysed by platinum on rutile-anatase structured titania. Chem Commun 56(11):1657-1660

48. Shi L, Qi S, Qu J, Che T, Yi C, Yang B (2019) Integration of hydrogenation and dehydrogenation based on dibenzyltoluene as liquid organic hydrogen energy carrier. Int J Hydrogen Energy 44:5345-5354

49. Jiang Z, Gong X, Wang B, Wu Z, Fang T (2019) A experimental study on the dehydrogenation performance of dodecahydro$\mathrm{N}$-ethylcarbazole on $\mathrm{M} / \mathrm{TiO}_{2}$ catalysts. Int J Hydrogen Energy 44(5):2951-2959

50. Yang M, Dong Y, Fei S, Ke H, Cheng H (2014) A comparative study of catalytic dehydrogenation of perhydro-N-ethylcarbazole over noble metal catalysts. Int J Hydrogen Energy 39:18976-18983
51. Wang B, Chang T, Jiang Z, Wei J, Zhang Y, Yang S, Fang T (2018) Catalytic dehydrogenation study of dodecahydro-N-ethylcarbazole by noble metal supported on reduced graphene oxide. Int J Hydrogen Energy 43:7317-7325

52. Dong Y, Yang M, Zhu T, Chen X, Cheng G, Ke H, Cheng H (2018) Fast dehydrogenation kinetics of perhydro-N-propylcarbazole over a supported Pd catalyst. ACS Appl Energy Mater 1:4285-4292

53. Zhu T, Yang M, Chen X, Dong Y, Zhang Z, Cheng H (2019) A highly active bifunctional Ru-Pd catalyst for hydrogenation and dehydrogenation of liquid organic hydrogen carriers. J Catal 378:382-391

54. Xue W, Liu H, Mao B, Liu H, Qiu M, Yang C, Chen X, Sun Y (2021) Reversible hydrogenation and dehydrogenation of N-ethylcarbazole over bimetallic $\mathrm{Pd}-\mathrm{Rh}$ catalyst for hydrogen storage. Chem Eng J. https://doi.org/10.1016/j.cej.2020.127781 (in press)

55. Wang B, Chang T, Jiang Z, Wei J, Fang T (2019) Component controlled synthesis of bimetallic $\mathrm{PdCu}$ nanoparticles supported on reduced graphene oxide for dehydrogenation of dodecahydroN-ethylcarbazole. Appl Catal B 251(15):261-272

56. Feng Z, Chen X, Bai X (2020) Catalytic dehydrogenation of liquid organic hydrogen carrier dodecahydro-N-ethylcarbazole over palladium catalysts supported on different supports. Environ Sci Pollut Res 27:36172-36185

57. Ding C, Zhu T, Wang F, Zhang Z, Dong Y, Yang M, Cheng G, Ke H, Cheng H (2020) High active Pd@mil-101 catalyst for dehydrogenation of liquid organic hydrogen carrier. Int J Hydrogen Energy 45:16144-16152

Publisher's Note Springer Nature remains neutral with regard to jurisdictional claims in published maps and institutional affiliations. 